\title{
Studies on Proteolytic Activity of Mycoplasmas: Gelatinolytic Property
}

\author{
By J. W. CZEKALOWSKI, D. A. HALL AND P. R. WOOLCOCK* \\ Division of Virology of the Microbiology Department and Department of Medicine, \\ School of Medicine, University of Leeds, Leeds, LS2 $9 \mathrm{NL}$
}

(Received I7 April 1972; revised I6 November 1972)

\begin{abstract}
SUMMARY
Twelve species of Mycoplasma, comprising I5 strains, were examined for proteolytic activity. Only Mycoplasma arthritidis, strains PG6 and PG27, liquefied gelatin. The active principle shows enzymatic properties, appears both intra- and extracellularly and attacks only denatured collagen being without effect on native collagen and elastic tissue. The value of proteolytic activity as a taxonomic marker is discussed.
\end{abstract}

\section{INTRODUCTION}

Proteolytic activities of mycoplasma have not been extensively investigated. Mycoplasma mycoides liquefies heat-coagulated animal sera; the caprine variety does so with both sheep and goat sera (Longley, I95I), whereas the bovine variety only acts on ox serum, though less vigorously than the former (Freundt, I958). Freundt (I958) demonstrated proteolytic properties for both varieties of $M$. mycoides, $M$. canis and the saprophytic $M$. laidlawii on gelatin treated with formalin (Kohn, 1953) and this was confirmed for M. laidlawii, strains A and B, and for M. mycoides var. capri by Razin \& Oliver (I96I) who grew the organisms on Edward's medium (Edward, 1947) solidified with gelatin instead of agar. Recently Aluotto, Wittler, Williams \& Faber (1970) carried out a comprehensive investigation of the biochemical properties, including digestion of coagulated serum and hydrolysis of gelatin, on many species and strains of Mycoplasmatales. Their work added to the list of organisms attacking gelatin four out of the five strains of $M$. arthritidis examined, but did not confirm this activity for $M$. canis or $M$. laidlawii, strains A and B, for which it had been claimed by Freundt (1958). We have examined a number of strains of mycoplasmas and acholeplasmas for proteolytic activity to establish whether the property might be more common than has so far been recognized (Czekalowski, Hall \& Woolcock, 1971; 1972).

\section{METHODS}

Organisms. The following mycoplasmas and acholeplasmas, all received from Dr D. Taylor-Robinson, were investigated: Mycoplasma agalactiae, strain PG2; M. arthritidis, strains PG6 and PG27; M. fermentans, strain PGI8; M. hominis, strains PG2I and DC63; $M$. hyorhinis, strain $\mathrm{BTS} 7 ; M$. iners, strain $\mathrm{PG} 30 ; M$. orale type I, strain CHI9299; $M$. orale type II, strain $\mathrm{CH} 20247$; M. pulmonis, strain KON; M. salivarium, strain PG2O; Acholeplasma granularum, strain BTS39; A. laidlawii, strains PG8(A) and PG9(B). N.B. Mycoplasma laidlawii and Mycoplasma granularum have been reclassified as Acholeplasma laidlawii and Acholeplasma granularum, respectively (Edward \& Freundt, I970).

* Present address: The Animal Health Trust, Small Animals Centre, Lanwades Park, Kennett, near Newmarket, Suffolk. 


\section{Cultivation of mycoplasmas and acholeplasmas}

Media for the cultivation of mycoplasma, based on the recommendation of Chanock, Hayflick \& Barile (I962) and Hayflick (I965), consisted of Difco PPLO Broth (70\%), boiled yeast extract (10\%) and unheated horse serum $(20 \%)$. When the whole horse serum was replaced by I \% Difco PPLO Serum Fraction (see below) the amount of broth was increased to $89 \%$. Solid media were prepared from the above by dissolving either $\mathrm{I} \cdot 4 \%$ Oxoid agar no. I or Ionagar no. 2 or $5 \%$ gelatin (all w/v) in boiling PPLO Broth and adding the other components after cooling to $45^{\circ} \mathrm{C}$. The agar medium was distributed in $5 \mathrm{ml}$ vol. into $5 \mathrm{~cm}$ diam. Petri dishes and the gelatin medium in $2 \mathrm{ml}$ vol. into screw-capped bijou bottles. To prevent bacterial growth in the gelatin medium, thallium acetate and penicillin $\mathrm{G}$ were added to final concentrations of $\mathrm{I}$ in 2000 and $200 \mathrm{u} / \mathrm{ml}$, respectively.

PPLO Broth consisted of $2 \mathrm{I} \mathrm{g}$ powdered 'Difco PPLO Broth' dissolved in $\mathrm{I} 1$ of deionized water, sterilized by autoclaving at $103 \mathrm{kN} / \mathrm{m}^{2}\left(\mathrm{I} 5 \mathrm{lb} / \mathrm{in}^{2}\right)$ for $\mathrm{I} 5 \mathrm{~min}$ and stored at room temperature.

Yeast extract was prepared by suspending $250 \mathrm{~g}$ dried baker's yeast in $\mathrm{I} 1$ of deionized water, bringing the mixture to the boil and simmering it for $30 \mathrm{~min}$. The extract clarified by centrifuging at $3750 \mathrm{~g}$ for $30 \mathrm{~min}$ followed by a preliminary filtration through Whatman no. I filter paper and finally passed through a membrane filter (Sartorius) of $0.42 \mu \mathrm{m}$ porosity, gave a clear solution which was sterilized by autoclaving at $69 \mathrm{kN} / \mathrm{m}^{2}$ ( $\mathrm{Io} \mathrm{lb} / \mathrm{in}^{2}$ ) for $10 \mathrm{~min}$. The extract was stored at $-70{ }^{\circ} \mathrm{C}$ and retained its quality for at least one year.

Horse serum, sterile but unheated, was obtained either from Burroughs Wellcome Ltd, Beckenham, Kent, or from Fraburg Ltd, Maidenhead, Berkshire and was stored at $4{ }^{\circ} \mathrm{C}$. For incorporation into substrates for the assay of elastase (see below) the serum was digested with pepsin as follows: to $100 \mathrm{ml}$ of serum, adjusted to $\mathrm{pH} 3.2$ with $\mathrm{N}-\mathrm{HCl}$, $6.0 \mathrm{ml}$ of $0.5 \%$ (w/v) suspension of pepsin (British Drug Houses Ltd, Poole, Dorset) was added and the mixture shaken until the pepsin had dissolved; the $\mathrm{pH}$ was readjusted to 3.2 when necessary; the mixture was incubated at $30^{\circ} \mathrm{C}$ for $30 \mathrm{~min}$ and then neutralized to $\mathrm{pH} 7 \cdot 0$ with $\mathrm{N}-\mathrm{NaOH}$; pepsinized serum was sterilized by filtration through a Seitz filter and stored at $4{ }^{\circ} \mathrm{C}$.

Serum fraction. In later experiments the whole serum was replaced by Difco PPLO Serum Fraction at a concentration of $\mathrm{I} \%$, thus reducing considerably the amount of extraneous protein present in culture filtrates (cf. Woolcock, Czekalowski \& Hall, I973). Stock solutions were prepared at a concentration of $5 \%$, sterilized by passage through a Seitz filter and stored at $4{ }^{\circ} \mathrm{C}$.

Phosphate-buffered saline (PBS/A) (Dulbecco \& Vogt, 1954) was prepared from $\mathrm{Na}_{2} \mathrm{HPO}_{4}$ and $\mathrm{KH}_{2} \mathrm{PO}_{4}$ at a molarity of $0 \cdot \mathrm{I} 3 \mathrm{M}$ and at the various $\mathrm{pH}$ values mentioned in the text.

Penicillin. Penicillin G (Glaxo Laboratories, Greenford, Middlesex) was prepared as an aseptic stock solution of $10000 \mathrm{u} / \mathrm{ml}$ and stored at $-15{ }^{\circ} \mathrm{C}$.

Thallium acetate. Stock solutions of thallium acetate in distilled water $(5 \%$, w/v) were sterilized in a Seitz filter and stored at $4{ }^{\circ} \mathrm{C}$.

Gelatin. Four proprietary brands of gelatin (British Drug Houses Ltd; Difco, Detroit, Michigan, U.S.A.; Griffin \& George, Wembley, Middlesex; and Oxoid, London) were chosen for evaluation as possible substrates for gelatinase assay. The essential requirements of a suitable gelatin are that it should be capable, when dissolved in PBS or in the complete PPLO growth medium, of producing a firm gel at low concentrations; the gel should withstand repeated warming to $37^{\circ} \mathrm{C}$ and cooling to $4{ }^{\circ} \mathrm{C}$ for between 7 and 10 days without impairment of its ability to gel. Difco gelatin appeared more sensitive to 
liquefaction by the active principle than the other brands examined and produced more consistent results, thus answering the demanding criteria of the controls; its use was, therefore, adopted for all the experiments reported in this paper.

Growth of mycoplasmas and acholeplasmas was carried out either in liquid or on solidified media. A $0.1 \mathrm{ml}$ sample of a 3-day-old culture served as the inoculum for each $0.9 \mathrm{ml}$ of the liquid PPLO medium distributed into bijou bottles. Before incubation the caps of the bottles were loosened to allow free gaseous exchange with moist aerobic $\left(5 \% \mathrm{CO}_{2}, 95 \%\right.$ air, $\mathrm{v} / \mathrm{v})$ or anaerobic $\left(5 \% \mathrm{CO}_{2}, 95 \% \mathrm{~N}_{2}, \mathrm{v} / \mathrm{v}\right)$ atmospheres provided externally. Larger quantities of the organisms were obtained by growing aerobically at $37^{\circ} \mathrm{C}$ for 6 days in $200 \mathrm{ml}$ of PPLO growth medium dispensed into $250 \mathrm{ml}$ flat bottles. Media solidified with agar were inoculated by spreading over the surface $0 . \mathrm{I} \mathrm{ml}$ of tenfold serial dilutions of liquid cultures in PPLO Broth; growth was assessed by counting the colonies.

Identification of gelatin-liquefaction activity. Growth medium containing $5 \%(\mathrm{w} / \mathrm{v})$ gelatin was seeded in duplicate with liquid cultures of the organisms and incubated at $37^{\circ} \mathrm{C}$, the temperature recommended by Manchee \& Taylor-Robinson (I968), for between 6 and Io days under either aerobic or anaerobic conditions. From the third day of incubation the bottles were daily chilled at $4{ }^{\circ} \mathrm{C}$ for $\mathrm{I} \mathrm{h}$ and then inverted to assess the degree of liquefaction. Controls, consisting of uninoculated media, were treated identically.

For the detection of gelatinolytic activity in culture supernatants or sonicated organisms the substrate consisted of gelatin without added broth or serum. Gelatin $(3 \%$, w/v) in PBS/A $(0.13 \mathrm{M}, \mathrm{pH} 7.4)$, tris- $\mathrm{HCl}$ buffer $(0.05 \mathrm{M}, \mathrm{pH} 7.4)$ or deionized water was dispensed in I $\mathrm{ml}$ volumes in bijou bottles and sterilized by autoclaving at $103 \mathrm{kN} / \mathrm{m}^{2}$ for $\mathrm{I} 5 \mathrm{~min}$. After cooling to $37^{\circ} \mathrm{C}$ they were ready for inoculation. Growth of contaminants was avoided by the addition of $\mathrm{I} 00 \mathrm{u}$ penicillin $/ \mathrm{ml}$ and $\mathrm{I} 00 \mu \mathrm{g}$ streptomycin/ml to each bottle. These antibiotics were without effect on the stability of the gel or the activity of the enzyme.

Detection of gelatinolytic activity in culture supernatants or sonicated organisms. Supernatant ( $\mathrm{I} \mathrm{ml}$ ) from cultures of the various organisms was added to the $\mathrm{I} \mathrm{ml}$ of gelatin substrate and the mixture maintained at $37{ }^{\circ} \mathrm{C}$ for 3 days. At this point the bottles were cooled for $\mathrm{I} h$ and the degree of liquefaction assessed. All bottles giving negative readings were re-incubated for a further 3 days with daily cooling and checking.

\section{Assay methods for collagenase and elastase}

Insoluble collagen. A suspension in deionized water $(2 \%, \mathrm{w} / \mathrm{v})$ of insoluble collagen (Bowes \& Kenten, I948) prepared from hide powder or achilles tendon was sterilized by exposure in Petri dishes to u.v. irradiation (Hannovia u.v. 'Chromatolite' unit, starting $0.5 \mathrm{~A}$, total $30 \mathrm{~W}$ ) for $2 \mathrm{~h}$ at $30 \mathrm{~cm}$ distance from the source of irradiation and stored as a stock suspension at $4{ }^{\circ} \mathrm{C}$. This material was diluted to $0 \cdot 2 \%(\mathrm{w} / \mathrm{v}$ final concentration) with 0.13 M-PBS, $\mathrm{pH}_{7} \cdot 6$, containing $\mathrm{I} \cdot 4 \%$ Oxoid agar no. $\mathrm{I}$ and poured into sterile Petri dishes.

Collagenase. Stock solutions of collagenase (Worthington Biochemicals, Freehold, New Jersey, U.S.A.) in $0.13 \mathrm{M}$-PBS/A, $\mathrm{pH} 7 \cdot 6$, were prepared, sterilized by ultrafiltration through an Amicon Diaflo membrane no. PM 30 (Amicon Ltd, High Wycombe, Buckinghamshire) and stored at $4{ }^{\circ} \mathrm{C}$.

Assessment of collagenase activity. Wells were punched in the collagen-agar plates with a no. 4 cork borer and, to prevent leakage, the bottom of each well was sealed with a small drop of molten agar. Each well held $\mathrm{O} \cdot \mathrm{I} \mathrm{ml}$ of culture filtrate or standard collagenase solution, which was allowed to diffuse overnight into the surrounding agar gel at $4{ }^{\circ} \mathrm{C}$. The Petri dishes were then transferred to an incubator at $37^{\circ} \mathrm{C}$ for aerobic incubation in a 
Table I. The effect of PPLO growth medium and its components on collagenase and collagen

Test sample

Collagenase $100 / \mu \mathrm{g} / \mathrm{ml}$ (Control)

Fraburg horse serum

Burroughs Wellcome horse serum

Yeast extract

PPLO broth

Complete PPLO growth medium

Collagenase + Fraburg horse serum

Collagenase + Burroughs Wellcome horse serum

Collagenase + yeast extract

Collagenase + PPLO broth

Collagenase + complete PPLO growth medium

o. I 3 M-PBS/A, pH 8

+ , Digestion of native collagen; -, no effect.
Effect on native collagen

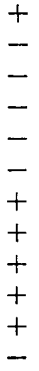

Table 2. The effect of pepsin and pepsinized horse serum on elastin and elastase

Test sample

Elastase $100 / \mu \mathrm{g} / \mathrm{ml}$ (Control)

Pepsin ( $0.1 \%$ in PBS/A

Elastase + pepsin

Elastase + Fraburg Horse serum

Pepsinized Fraburg horse serum

Elastase + pepsinized Fraburg horse serum

Elastase + Burroughs Wellcome horse serum

Elastase + pepsinized Burroughs Wellcome horse serum

\section{Effect on \\ elastin}

+
-
+
-
+
-
+ + , Digestion of elastin; -, no effect.

moist atmosphere. Clear areas were observed around the wells containing collagenase. No inhibitory effect of horse serum on collagenase has been observed (Table I).

Elastin. Prepared from bovine nuchal ligament, was purified by treatment with $2 \%$ acetic acid according to the method of Hall (I955). A suspension ( $2 \%, w / v)$ of elastin powder ( 100 to I $20 \mathrm{mesh} / \mathrm{in}$ ) in deionized water was sterilized by tyndallization at $75^{\circ} \mathrm{C}$ for $30 \mathrm{~min}$ on 3 successive days, with intermediate incubation at $37^{\circ} \mathrm{C}$. This stock suspension was stored at $4{ }^{\circ} \mathrm{C}$. For use as an assay medium for elastase, Petri dishes were poured with a mixture consisting of $0 \cdot \mathrm{I} \%(\mathrm{w} / \mathrm{v})$ elastin suspension (final concentration) and $\mathrm{I} \cdot 4 \%$ Oxoid no. I agar dissolved in $0.13 \mathrm{M}$-PBS/A, $\mathrm{pH} 8.4$.

Elastase. Stock solutions of elastase (Hall \& Czerkawski, 1959) in 0.13 M-PBS/A, pH 8*4, were prepared, sterilized and stored as described for collagenase.

Assessment of elastase activity. Using elastin-agar plates the elastase activity was demonstrated in an exactly similar fashion to that employed for the demonstration of collagenase activity. Preliminary observations indicated clearly that horse serum contains an elastase inhibitor. To prevent such an inhibitor obscuring the activity of any possible elastolytic enzymes evolved by the mycoplasmas, pepsinized serum was employed in the growth media, since this treatment could be shown to inactivate the inhibitor. (Table 2).

Ultrasonic treatment of mycoplasma. Mycoplasma culture $(300 \mathrm{ml})$ was sedimented by centrifugation at $60000 \mathrm{~g}$ (Christ Omega II centrifuge) for $45 \mathrm{~min}$. The pellet was resuspended in saline buffered to $\mathrm{pH} 7.4$ with $0.05 \mathrm{M}$-tris- $\mathrm{HCl}$ buffer and resedimented as 
before. This washing process was repeated twice. Finally, the pellet was resuspended in $3 \mathrm{ml}$ of tris buffer and the suspension divided into three samples. Two samples were treated in a Ultrasonic disintegrator (MSE 100 ) at maximum amplitude (6 to $7 \mu \mathrm{m}$ ) on the autosetting for 4 and $10 \mathrm{~min}$, respectively, and the third served as an untreated control. During sonication the reaction vessel was chilled to o ${ }^{\circ} \mathrm{C}$.

\section{RESULTS}

As our objective was to determine whether the mycoplasmas examined possess proteolytic activity for gelatin, both the complete growth medium and its ingredients were first screened for their effect on gelatin. The results indicated that only the horse serum may affect the firmness of the gelatin gel, a finding of some practical importance since the more fastidious mycoplasmas require as much as $20 \%$ serum for their growth. Certain batches of both Burroughs Wellcome and Fraburg brands of horse serum softened gelatin gel per se and, therefore, batches free of this activity were selected and used throughout these experiments.

In screening for gelatinolytic property, the mycoplasmas were cultivated in complete PPLO growth medium solidified with $5 \%$ gelatin. A possibility that slight gelatinolytic activity of certain organisms might be masked by high protein content has been avoided by substituting for horse serum the Difco PPLO Serum Fraction, with a consequent reduction in total protein added. However, both types of media inoculated in parallel produced identical results.

Of ten species ( 2 strains) of mycoplasmas and two species (three strains) of acholeplasmas examined for gelatinolytic activity only the two strains (PG6 and PG27) of Mycoplasma arthritidis liquefied gelatin (Table 3 ).

Further experiments were designed to establish whether the active principle is independent of the viability of the organisms and, if so, whether it is present within the mycoplasma cell or extracellularly, or in both situations. For this purpose, fluid cultures of Mycoplasma arthritidis were centrifuged, the supernatant separated and the sedimented organisms disrupted by ultrasonication. The supernatant, whole organisms and the two preparations obtained by different periods of sonication were examined for gelatinolytic activity, and the results obtained for each $M$. arthritidis strain indicate that the liquefying principle is present in all of them. The substrate alone is incapable of supporting the growth of mycoplasmas, hence the activity of the unsonicated sample of the sediment must be attributed to the action of an active principle liberated from spontaneously decomposing organisms.

This active principle shows enzymatic properties, being both thermolabile, in that the filtrates of the metabolic fluid lose all activity after heating at $60{ }^{\circ} \mathrm{C}$ for $30 \mathrm{~min}$, and also in attacking gelatin, as is evidenced by the loss of regelification of the substrate at low temperature.

As gelatins represent a denatured form of collagen it was proper to examine the action of the gelatinolytic principle on native collagen; the effect on elastin was also studied. Preliminary results showed that horse sera per se did not inhibit collagenase (Table I) but inhibited elastase (Table 2). To avoid the possibility of instant inactivation of elastase, should it be produced in Mycoplasma arthritidis cultures, growth medium was enriched with pepsinized horse serum. The results obtained in systems based on native collagen and on elastin were negative, thus suggesting the absence of the specific enzymes for these substrates from cultures of PG6 and PG27 strains of M. arthritidis. 
Table 3. Gelatinolytic property of mycoplasmas and acholeplasmas

\begin{tabular}{|c|c|c|c|c|}
\hline Species & Strain & \multirow{2}{*}{$\begin{array}{l}\text { Carbohydrate* } \\
\text { fermentation }\end{array}$} & \multirow{2}{*}{$\begin{array}{l}\text { Liquefaction } \\
\text { of gelatin }\end{array}$} & \multirow[b]{2}{*}{ Reference $\nmid$} \\
\hline Mycoplasmas & & & & \\
\hline Mycoplasma bovirhinis & PG43 & + & - & I \\
\hline M. felis & $\mathrm{CO}$ & + & - & I \\
\hline M. fermentans & $\begin{array}{l}5 \text { strains } \\
\text { PG I } 8 \\
\text { GII } \\
67-166\end{array}$ & $\begin{array}{l}+ \\
+ \\
+ \\
+\end{array}$ & $\begin{array}{l}- \\
- \\
-\end{array}$ & $\begin{array}{r}2 \\
\mathrm{I}, 3 \\
\mathrm{I} \\
\mathrm{I}\end{array}$ \\
\hline M. gallisepticum & $\begin{array}{l}\text { PG3I } \\
\text { s6 }\end{array}$ & $\begin{array}{l}+ \\
+\end{array}$ & $\begin{array}{l}- \\
-\end{array}$ & $\begin{array}{l}\text { I } \\
\text { I }\end{array}$ \\
\hline M. histotropicum & Sabin, Type C & + & - & I \\
\hline M. hyorhinis & $\begin{array}{l}\text { BTS7 (PG42) } \\
\text { GDL } \\
\text { PG29 } \\
\text { BTS7 } \\
\text { PG29 }\end{array}$ & $\begin{array}{l}+ \\
+ \\
+ \\
-\end{array}$ & $\begin{array}{l}- \\
- \\
- \\
- \\
-\end{array}$ & $\begin{array}{r}1 \\
I \\
1 \\
2,3 \\
2,3\end{array}$ \\
\hline M. mycoides mycoides & Paris 1950 & + & + & 2 \\
\hline M. mycoides capri & PG3 & + & + & 2 \\
\hline M. neurolyticum & $\begin{array}{l}\text { Sabin, type A } \\
\text { KSA } \\
\text { L5 } \\
205 \text { C }\end{array}$ & $\begin{array}{l}+ \\
+ \\
+ \\
+\end{array}$ & $\begin{array}{l}- \\
- \\
-\end{array}$ & $\begin{array}{l}1 \\
1 \\
2 \\
2\end{array}$ \\
\hline M. pneumoniae & $\begin{array}{l}\text { FH } \\
\text { Bru } \\
\text { Mac }\end{array}$ & $\begin{array}{l}+ \\
+ \\
+\end{array}$ & $\begin{array}{l}- \\
- \\
-\end{array}$ & $\begin{array}{l}\text { I } \\
\text { I } \\
\text { I }\end{array}$ \\
\hline M. pulmonis & $\begin{array}{l}\text { PG34 (Ash) } \\
\text { KON } \\
\text { Negroni } \\
\text { C3 OKS-I } \\
\text { PG24 }\end{array}$ & $\begin{array}{l}+ \\
+ \\
+ \\
+ \\
+\end{array}$ & $\begin{array}{l}- \\
- \\
- \\
- \\
-\end{array}$ & $\begin{array}{r}\mathrm{I}, 2 \\
\mathrm{I}, 3 \\
\mathrm{I} \\
\mathrm{I} \\
\mathrm{I}\end{array}$ \\
\hline M. agalactiae & $\left.\begin{array}{l}\mathrm{PG} 2 \\
\mathrm{PG} 2\end{array}\right\}$ & N.D. & - & $\begin{array}{l}\text { I } \\
3\end{array}$ \\
\hline M. arthritidis & $\begin{array}{l}\text { R3, R5, R6 } \\
\text { PG6 } \\
\text { PG27 } \\
\text { H606 } \\
\text { Jasmin }\end{array}$ & $\begin{array}{l}- \\
- \\
- \\
-\end{array}$ & $\begin{array}{l}- \\
+ \\
+ \\
+ \\
-\end{array}$ & $\begin{array}{r}2 \\
\mathrm{I}, 3 \\
\mathrm{I}, 3 \\
\mathrm{I} \\
\mathrm{I}\end{array}$ \\
\hline M. bovigenitalium & $\begin{array}{l}\text { CN2384 P } \\
\text { PGII }\end{array}$ & - & $\begin{array}{l}- \\
-\end{array}$ & $\begin{array}{l}2 \\
1\end{array}$ \\
\hline M. canis & $\begin{array}{l}\text { PGI4 (c55) } \\
\text { PGI4 (c55) }\end{array}$ & $\overline{+}$ & $\begin{array}{l}+ \\
-\end{array}$ & $\begin{array}{l}2 \\
\mathrm{I}\end{array}$ \\
\hline M. gallinarum & PGI 6 & - & - & $\mathrm{I}, 2$ \\
\hline M. gateae & Cs & - & - & I \\
\hline M. hominis & $\begin{array}{l}5 \text { strains } \\
\text { PG 2 I } \\
\text { DC63 } \\
4387 \\
\text { H34 }\end{array}$ & $\begin{array}{c}- \\
- \\
\text { N.D. } \\
- \\
-\end{array}$ & $\begin{array}{l}- \\
- \\
- \\
-\end{array}$ & $\begin{array}{r}\text { I } \\
\text { I, } 3 \\
3 \\
\text { I } \\
2\end{array}$ \\
\hline M. iners & $\begin{array}{l}\text { PG30 } \\
\text { A6oz }\end{array}$ & $\begin{array}{l}- \\
-\end{array}$ & $\begin{array}{l}- \\
-\end{array}$ & $\begin{array}{r}\text { I, } 3 \\
\text { I }\end{array}$ \\
\hline M. maculosum & PGI 5 (c27) & - & - & $\mathrm{I}, 2$ \\
\hline M. orale, type I & $\begin{array}{l}823 \mathrm{~B} \\
\text { CHI9299 }\end{array}$ & $\overline{\text { N.D. }}$ & - & $\begin{array}{l}\text { I } \\
3\end{array}$ \\
\hline
\end{tabular}


Table 3. (cont.)

\begin{tabular}{|c|c|c|c|c|}
\hline Species & Strain & & & \\
\hline \multicolumn{2}{|l|}{ Mycoplasmas } & fermentation & of gelatin & Referencei \\
\hline \multirow{2}{*}{ M. orale, type 2} & DCI 600 & - & - & 1 \\
\hline & $\mathrm{CH} 20247$ & N.D. & - & 3 \\
\hline M. pharyngis & Patt & - & - & I \\
\hline \multirow[t]{2}{*}{ M. salivarium } & PG2O & - & - & $1,2,3$ \\
\hline & Buccal I & - & - & I \\
\hline M. spumans & PGI3 (C48) & - & - & $\mathrm{I}, 2$ \\
\hline M. primatum & Navel & - & - & I \\
\hline \multicolumn{5}{|l|}{ Acholeplasmas } \\
\hline Acholeplasma granularum & BTS39 & + & - & I, 3 \\
\hline \multirow{10}{*}{ A. laidawii } & A & + & + & 2 \\
\hline & A & + & - & I \\
\hline & в & + & + & 2 \\
\hline & B & + & - & I \\
\hline & Algen & + & + & 2 \\
\hline & BI 5 & + & + & 2 \\
\hline & $\mathrm{L}$ & + & + & 2 \\
\hline & Mist & + & + & 2 \\
\hline & PG8 (A) & + & - & I, 3 \\
\hline & PG9 (B) & + & - & $\mathrm{I}, 3$ \\
\hline
\end{tabular}

* The status of the tabulated organisms with respect to carbohydrate fermentation is included to indicate one of the accepted bases of biochemical classification.

$\dagger$ I, Aluotto et al. (1970); 2, Freundt (1958); 3, present paper.

+ , Positive; -, negative; N.D., not done

\section{DISCUSSION}

Our work and that of Aluotto et al. (1970) augmented the list of gelatinolytic mycoplasma species by adding Mycoplasma arthritidis, strains PG6 and PG27 and H606, but did not confirm this activity in A and B strains of $M$. laidlawii, as described by Freundt ( $195^{8}$ ). The discrepancy in the latter finding could be due to different methods used by the workers concerned. The composition of the gelatin medium of Aluotto et al. (1970) resembled that of ours, except in the concentration of gelatin, in substituting Difco Heart Infusion Broth for Difco PPLO Broth and in using inactivated horse serum which in our experience had lower growth-promoting property than the untreated serum. Freundt (I958) used formalinhardened gelatin (Kohn, 1953) and noticed in controls that, when immersed in culture medium rich in ascitic fluid $(30 \%)$, the gelatin strips underwent spontaneous 'decomposition'. He suggested that this non-specific reaction was due to proteolytic enzymes present in the ascitic fluid or to some other unknown factors. J. W. Czekalowski and D. A. Hall (unpublished observations) confirmed Freundt's (1958) findings with formalin-denatured gelatin and noticed that certain ascitic fluids liquefied the untreated gelatins within the time required by proteolytic mycoplasmas to attack gelatin-solidified growth media enriched with selected horse sera free of gelatinolytic activity. It is, therefore, our view that the method used by Freundt (1958) could have been 'over-sensitive' and for this reason less accurate, offering a possibility of false positive results. This may account for the differences in the results obtained by Freundt (1958) and ourselves when assessing the gelatinolytic activity of $A$. laidlawii, strains A and $\mathrm{B}$, and also for those between the findings of Freundt (1958) and Aluotto et al. (1970) for M. canis. This assumes, of course, that in both instances the strains examined were identical. 
By adding to the species described in the literature those examined by us, 27 species in all, comprising 77 strains, have so far been examined for gelatinolytic activity (Table 3 ). This property has only been found in five species, comprising I 2 strains, bringing to $18.5 \%$ the number of positive species ( $16 \%$ of strains) of all those examined. These findings should not be overlooked as they evidently set the positive organisms apart from the negative ones and the test for gelatinolytic activity may represent an additional property of taxonomic value.

Taxonomy is based on biological markers whose individual values are not necessarily of the same dimension, e.g. the habitat and pathogenicity as taxonomic properties of microorganisms are not necessarily always of the same importance as are those biological properties which are assessable in vitro. This is particularly pertinent to mycoplasmas (Edward, 1967).

We believe that in mycoplasmas the test for gelatinolytic activity might serve a useful purpose, as only certain species among both carbohydrate-fermenting and non-fermenting organisms possess this property. Though the studies carried out so far concern primarily the biochemist, they ought to attract increasing interest on the part of taxonomists.

Undoubtedly, more investigation into the gelatinolytic properties of mycoplasmas is required, with a special attention being directed towards methodology. To exclude false or doubtful results, attention is drawn to the importance of selecting the proper brand of gelatin and batch of horse serum. It is possible that under strictly controlled experimental conditions certain strains described by Freundt (1958) as doubtful in respect of the gelatinolytic activity may turn out as negative; also Acholeplasma granularum, being nonproteolytic, may on this ground retain its species identity in spite of antigenic and fermentative resemblance to $A$. laidlawii (Tully \& Razin, 1968).

\section{CONCLUSION}

The gelatinolytic principle of Mycoplasma arthritidis appears within the organisms and is secreted into the metabolic fluid. It appears to be enzymatic in nature and only attacks denatured collagen in the form of gelatin, having no effect either on native collagen or on elastic tissue. The view is expressed that the gelatinolytic property may contribute to the taxonomy of mycoplasmas.

The work reported in this paper was partly supported by a Research Training Grant from the Agricultural Research Council (U.K.) to one of us (P.R.W.) for which we are grateful. We also wish to thank Dr D. Taylor-Robinson, M.R.C. Clinical Research Centre, Harvard Hospital, Salisbury, Wiltshire, for kindly supplying us with the strains of $\mathrm{MyCo}$ plasma used in our studies.

\section{REFERENCES}

Aluotto, B. B., Wittler, R. G., Williams, C. O. \& Faber, J. E. (1970). Standardized bacteriological techniques for the characterization of mycoplasma species. International Journal of Systematic Bacteriology 20, 35-58.

Bowes, J. H. \& Kenten, R. H. (1948). The amino acid composition and titration curve of collagen. Biochemical Journal 43, 358-365.

Chanock, R. M., Hayflick, L. \& Barile, M. F. (1962). Growth on an artificial medium of an agent associated with atypical pneumonia and its identification as a PPLO. Proceedings of the National Academy of Science of the United States of America 48, 4I-49. 
Czekalowski, J. W., Hall, D. A. \& Woolcock, P. R. (I97I). Proteolytic activity of mycoplasma strains associated with arthritis. (Proceedings of the I 22nd meeting of the Pathological Society of Great Britain and Ireland). Journal of Medical Microbiology 4, iv.

Czekalowski, J. W., Hall, D. A. \& Woolcock, P. R. (1972). Proteolytic activity of mycoplasma arthritidis. The Heberden Society Annual General Meeting. Annals of the Rheumatic Diseases 3r, 428.

Dulbecco, R. \& VoGT, M. (I954). Plaque formation and isolation of pure lines with poliomyelitis viruses. Journal of Experimental Medicine 99, 167-182.

EDWARD, D. G. FF. (1947). A selective medium for pleuropneumonia-like organisms. Journal of General Microbiology $\mathbf{1}, 238-243$.

EDWARD, D. G. FF. (1967). Classification of mycoplasma of man. First International Conference on Vaccines against Viral and Rickettsial Diseases of Man, pp. I 20-124. Washington: D.C.: Pan American Health Organization.

Edward, D. G. Ff. \& Freundt, E. A. (1970). Amended nomenclature for strains related to Mycoplasma laidlawii. Journal of General Microbiology 62, I-2.

Freundt, E. A. (1958). The Mycoplasmataceae (The Pleuropneumonia Group of Organisms, Morphology, Biology and Taxonomy). Copenhagen: Munksgaard.

HaLl, D. A. (I955). The reaction between elastase and elastic tissue. I. The substrate. Biochemical Journal 59, 459-464.

Hall, D. A. \& Czerkawski, J. W. (1959). The purification of the proteolytic component of elastase. Biochemical Journal 73, 356-36I.

Hayflick, L. (1965). Tissue cultures and mycoplasmas. Texas Reports on Biology and Medicine 23, $285-303$.

Конn, J. (1953). A preliminary report of a new gelatin liquefaction method. Journal of Clinical Pathology $6,249$.

Longley, E. O. (195I). Contagious Caprine Pleuropneumonia. A Study of the Disease in Nigeria. Coionial Research Publications No. 7. London: H.M. Stationery Office.

MANCHEE, R. J. \& TAYLOR-RoBinson, D. (I968). Haemadsorption and haemagglutination by mycoplasmas. Journal of General Microbiology 50, 465-478.

Razin, S. \& Oliver, Ofra. (I96I). Morphogenesis of mycoplasma and bacterial L-form colonies. Journal of General Microbiology 24, 225-237.

Tully, J. G. \& Razin, S. (1968). Physiological and serological comparisons among strains of Mycoplasma granularum and Mycoplasma laidlawii. Journal of Bacteriology 95, I 504-I 5 I 2.

Woolcock, P. R., Czekalowski, J. W. \& Hall, D. A. (I973). Studies on proteolytic activity of mycoplasmas: The preparation of gelatinolytic enzymes from strains of Mycoplasma arthritidis. Journal of General Microbiology (in the press). 